accountancy; internationalization of Bentley's programs by increasing the number of partnership agreements and expanding the international studies department; the creation of Bentley's Alliance for Ethics and Social Responsibility; the opportunity for business majors to take a second liberal studies major; the introduction of a joint MS + MBA degree, and a $\$ 16$ million renovation of the library that includes expansion of Bentley's physical and electronic collections.

Previously Professor of Information Systems and Research Director in the Department of Information Systems at the London School of Economics, he retains his connection with the LSE as a Visiting Professor. Before joining LSE, Professor Galliers served as Lucas Professor of Business Management Systems and Dean of the Warwick Business School in the United Kingdom, and earlier as Foundation Professor and Head of the School of Information Systems at Curtin University in Australia

Professor Galliers holds an $\mathrm{AB}$ degree with honors in Economics from Harvard University, an MA with distinction in Management Systems from Lancaster University, and a Ph.D. in Information Systems from the London School of Economics. He was awarded an Honorary Doctor of Science degree by the Turku School of Economics and Business Administration in Finland in 1995 for his contributions to European Information Management research.

He is a Fellow of the Royal Society of Arts, the British Computer Society, and the Association for Information Systems, of which he was President in 1999. He has chaired previous ICIS and ECIS conferences, and has been a keynote speaker at ECIS and ACIS, among others. He is editor-in-chief of the Journal of Strategic Information Systems and on the editorial boards of a number of other major journals. He has authored over 60 journal articles and a number of books, the most recent being Exploring Information Systems Research Approaches (Routledge, 2006) with Lynne Markus and Sue Newell, the third edition of the best-selling Strategic Information Management(Butterworth-Heinemann, 2003) with Dorothy Leidner, and Rethinking Management Information Systems (Oxford University Press, 1999) with Wendy Currie.

\title{
BUSINESS RESILIENCE IN A GLOBAL ECONOMY
}

\section{Rory O'Connor}

Mr. O'Connor's presentation will cover four basic themes.

- Doing Business - Doing Business Globally. Mr. O’Connor will discuss the challenges of doing business in today's global economy. Following a quick look at the anatomy of any business, he will review some of the structural and implementation choices available to the global business player today.

- The Impact of Modern Information and Communications Technology. Mr. O'Connor will review the impact that modern information systems and communications technology is having on our ability to access, manage, and control information and what that means in terms of choice for business success. 
- The Importance of the "Tribe." Mr. O'Connor will move on to look at the importance of identity to all of the stakeholders in business and how that influences strategic choices.

- Strategic Business Innovation-The MNC/Indigenous Challenge. "Keepin' on keepin' on"- finally, Mr. O'Connor will put forward some ideas on the need for new business models to resolve the cul-de-sac of "task-only" outsourced MNC activity. Using Ireland as an example, he will look at how we might forge new collaborative structures which will benefit not only the MNC but substantially transform indigenous industry.

Mr. O'Connor is Managing Director of Hewlett-Packard's European Software Centre. He is a 30-year veteran of the ICT sector, 15 of those years with the Irish Times where he played a leading role as IT manager in the delivery of the "new technology" in the 1970s. He joined Digital in 1986 as Ireland IS manager and moved to his first European role based in Galway in 1990. He was Worldwide Technology manager for Compaq's Software Manufacturing \& Distribution business from 1995 to 2000 and was appointed Managing Director of the European Software Centre in 2001. The Galway operation has continued to develop its technology and business operations in HP. The center specializes in R\&D in high performance technical computing, semantic Web technology and systems management tools and processes, software publishing services for the software industry, and software and Web management services for large multinational enterprises. 